\title{
THE CARBON DIOXIDE REQUIREMENT OF KLEBSIELLAE
}

\author{
G. BROOKES AND J. BARKER \\ Regional Public Health Laboratory, East Birmingham Hospital, \\ Bordesley Green East, Birmingham, B9 5ST
}

Plate I

THE REQUIREMENT of some brucellae, pneumococci and gonococci for carbon dioxide is well established. A strain of Staphylococcus aureus dependent on $\mathrm{CO}_{2}$ for characteristic growth was first recorded by Hale (1951) and subsequently there have been other reports of staphylococci with similar requirements (Thomas, 1977). This is a feature not usually associated with members of the Enterobacteriacae; however, we reported strains of Klebsiella that needed $\mathrm{CO}_{2}$ for growth (Barker, Brookes and Johnson, 1978) and a strain of Escherichia coli with this requirement was described by Eykyn and Phillips (1978).

This paper describes the growth of a variety of Klebsiellae in air with added $\mathrm{CO}_{2}$ and its relevance to the isolation and recognition of these organisms in the laboratory.

\section{MATERIALS AND METHODS}

Culture media. The following were used: MacConkey Agar (Oxoid) (without $\mathrm{NaCl}$ ); Columbia Agar (Oxoid) with defibrinated horse-blood added to a final concentration of $5 \%$ (v/v); Diagnostic Sensitivity Test Agar (DST) (Oxoid) with saponin-lysed defibrinated horseblood, added to give a final concentration of $5 \%(\mathrm{v} / \mathrm{v})$; and Nutrient Agar (Oxoid).

All the organisms were grown in $3 \mathrm{ml}$ of Peptone Water (Oxoid) for $6 \mathrm{~h}$ at $37^{\circ} \mathrm{C}$ to produce turbid suspensions containing approximately $10^{8}-10^{9}$ organisms $/ \mathrm{ml}$. These were then diluted in 100 -fold steps from 1 in $10^{2}$ to 1 in $10^{8}$ in quarter-strength Ringer's solution. One drop from a 50-dropper pipette of each dilution was seeded on the surfaces of the test plates which had been dried at $37^{\circ} \mathrm{C}$ for $45 \mathrm{~min}$. Paint tins of 2.5-litre capacity with airtight lids and holding 10 test plates, were used for incubation. The lids had a hole cut for a small rubber stopper, so that $10 \%$ $\mathrm{CO}_{2}$ could be injected by syringe and needle to give final concentrations of $0.07 \%, 0 \cdot 1 \%, 0 \cdot 18 \%$ and $3 \%(\mathrm{v} / \mathrm{v})$, neglecting the volume of the petri dishes in each tin.

Organisms. Ninety-five strains of Klebsiella were studied. They included strains from the National Collection of Type Cultures: K. ozaenae (NCTC nos. 9601, 9659, 9662 and 10313), K. pneumoniae (NCTC nos. 8849, 9635, 5056, 9637 and 9633), K. edwardsii var. edwardsii (NCTC nos. 5054, 8839, 10209, 7761 and 9616), K. edwardsii var. atlantae (NCTC nos. 9496, 10213, 9495, 9498 and 9617), K. rhinoscleromatis (NCTC nos. 5046, 10273, 5048, 7799 and 5047). The remaining strains were clinical isolates: 23 strains of $K$. ozaenae, 7 of $K$. edwardsii var. atlantae, one of $K$. pneumoniae and 40 of $K$. aerogenes; these were identified according to the scheme of Cowan (1974). The clinical isolates of $K$. ozaenae were also identified with API 20E biochemical strips from API Laboratory Products. 


\section{RESULTS}

\section{Effect of $\mathrm{CO}_{2}$ on growth}

The results of preliminary investigations on the growth of the organisms after incubation for $18 \mathrm{~h}$ at $37^{\circ} \mathrm{C}$ in air with $3 \%$ carbon dioxide are shown in table I. More than half the $K$. ozaenae strains showed a $10^{4}$ increase in viable count compared with parallel cultures in air; only one strain grew in air without additional $\mathrm{CO}_{2}$. There was no significant difference between the viable counts on blood or MacConkey agar except for three strains of $K$. rhinoscleromatis which failed to grow on the latter even after incubation in $\mathrm{CO}_{2}$. Four of the six $K$. pneumoniae, two of the $12 \mathrm{~K}$. edwardsii var. atlantae and one of the five $K$. edwardsii var. edwardsii strains showed enhanced growth in $\mathrm{CO}_{2}$ but this was not seen in any of the $K$. aerogenes or $K$. rhinoscleromatis strains.

Results similar to those shown in table I were obtained when cultures were incubated in air at $30^{\circ} \mathrm{C}$ - the concentration of $\mathrm{CO}_{2}$ in air is approximately $0.03 \%$. Although the viable count was the same, the colonies were only about $1 \mathrm{~mm}$ in diameter whereas with added $\mathrm{CO}_{2}$ at $37^{\circ} \mathrm{C}$ a diameter of $3 \mathrm{~mm}$ would be expected.

Some of the clinical strains exacting towards $\mathrm{CO}_{2}$, together with the NCTC organisms and a selection of $K$. aerogenes, were retested in air containing varying amounts of $\mathrm{CO}_{2}$ and incubated for $18 \mathrm{~h}$ at $30^{\circ} \mathrm{C}, 37^{\circ} \mathrm{C}$ and $41^{\circ} \mathrm{C}$. For each temperature two controls were set up; one to test for growth in air and the other for growth in the complete absence of $\mathrm{CO}_{2}$, achieved by passing air through a saturated solution of $\mathrm{KOH}$. The minimum concentration of $\mathrm{CO}_{2}$ required to give mucoid colonies of $3 \mathrm{~mm}$ diameter after incubation for $18 \mathrm{~h}$ is shown in table II. $K$. aerogenes was the only organism capable of growth at $30^{\circ} \mathrm{C}$ in the complete absence of $\mathrm{CO}_{2}$; all the remaining species grew at this temperature with the atmospheric level of $\mathrm{CO}_{2}$. At $37^{\circ} \mathrm{C}$ one NCTC strain of $K$. ozaenae grew in the absence of $\mathrm{CO}_{2}$ but the other 19 strains required a

TABLE I

Ability of $3 \% \mathrm{CO}_{2}$ to enhance the viable count of klebsiellae during incubation for $18 \mathrm{~h}$ at $37^{\circ} \mathrm{C}$ on horse-blood agar

\begin{tabular}{|c|c|c|c|}
\hline \multirow{2}{*}{$\begin{array}{l}\text { Klebsiella } \\
\text { species }\end{array}$} & \multicolumn{3}{|c|}{$\begin{array}{l}\text { Number of strains showing the indicated } \\
\text { enhancements of viable count in } 3 \% \mathrm{CO}_{2} \\
\text { compared with air }\end{array}$} \\
\hline & 10000 -fold & 100 -fold & None \\
\hline \multirow{3}{*}{$\begin{array}{l}\text { K. ozaenae } \\
\text { K. pneumoniae } \\
\text { K. rhinoscleromatis } \\
\text { K. edwardsii var. } \\
\text { atlantae } \\
\text { K. edwardsii var. } \\
\text { edwardsii } \\
\text { K. aerogenes }\end{array}$} & $\begin{array}{r}12 \\
2 \\
0\end{array}$ & $\begin{array}{r}10 \\
2 \\
0\end{array}$ & $\begin{array}{l}1 \\
2 \\
4\end{array}$ \\
\hline & 0 & 2 & 10 \\
\hline & $\begin{array}{l}0 \\
0\end{array}$ & $\begin{array}{l}1 \\
0\end{array}$ & $\begin{array}{r}4 \\
40\end{array}$ \\
\hline
\end{tabular}


TABLE II

Effect of incubation temperature and $\mathrm{CO}_{2}$ concentration on the production of normal-sized mucoid colonies by various klebsiellae after incubation for $18 \mathrm{~h}$

\begin{tabular}{|c|c|c|c|c|c|c|c|c|c|}
\hline \multirow{3}{*}{$\begin{array}{l}\text { Klebsiella species } \\
\text { (total number } \\
\text { of strains) }\end{array}$} & \multicolumn{9}{|c|}{ Number of strains giving normal-sized (3-4 mm diameter) mucoid colonies at ${ }^{*}$} \\
\hline & \multicolumn{2}{|c|}{$30^{\circ} \mathrm{C}$ in } & \multicolumn{3}{|c|}{$37^{\circ} \mathrm{C}$ in } & \multicolumn{4}{|c|}{$41^{\circ} \mathrm{C}$ in } \\
\hline & $\begin{array}{c}\mathrm{CO}_{2} \text {-free } \\
\text { air }\end{array}$ & air & $\begin{array}{c}\mathrm{CO}_{2} \text {-free } \\
\text { air }\end{array}$ & air & $\begin{array}{c}\text { air with } \\
0.07 \% \mathrm{CO}_{2}\end{array}$ & $\begin{array}{c}\mathrm{CO}_{2} \text {-free } \\
\text { air }\end{array}$ & air & $\begin{array}{c}\text { air with } \\
0.07 \% \mathrm{CO}_{2}\end{array}$ & $\begin{array}{c}\text { air with } \\
0.1 \% \mathrm{CO}_{2}\end{array}$ \\
\hline K. ozaenae $(20)$ & $\ldots$ & 20 & 1 & & 19 & & 1 & & $15+ \pm$ \\
\hline K. pneumoniae (4) & . & 4 & $\cdots$ & 1 & 3 & & $\cdots$ & 4 & $\ldots$ \\
\hline $\begin{array}{l}\text { K. edwarsii var. } \\
\text { atlantae }(5)\end{array}$ & & 5 & 1 & 2 & 2 & & & $5 \dagger$ & $\ldots$ \\
\hline K. aerogenes (5) & 5 & & 5 & $\ldots$ & $\ldots$ & 5 & $\ldots$ & $\ldots$ & $\ldots$ \\
\hline
\end{tabular}

* Organisms that grew at the lowest $\mathrm{CO}_{2}$ concentration also grew at the higher concentrations; air contains approximately $0.03 \% \mathrm{CO}_{2}$.

$\dagger$ Poor growth: colony size $c 1 \mathrm{~mm}$ diameter.

$\ddagger$ In addition, four strains failed to grow at $41^{\circ} \mathrm{C}$.

concentration above that of the atmosphere. When the incubation temperature was increased to $41^{\circ} \mathrm{C}$ the requirement for $\mathrm{CO}_{2}$ increased to $0.1 \%$. However, some organisms produced minute colonies, particularly the $K$. edwardsii var. atlantae strains and this growth limitation may have been influenced by the temperature. At $41^{\circ} \mathrm{C}$, only the $K$. aerogenes and $K$. pneumoniae strains grew well.

\section{Growth after deprivation of $\mathrm{CO}_{2}$}

Twenty strains of $K$. ozaenae and four strains of $K$. pneumoniae were inoculated on blood agar to give $10^{3}$ colony-forming units and incubated for 48 $h$ at $30^{\circ} \mathrm{C}$ and $41^{\circ} \mathrm{C}$ in the absence of $\mathrm{CO}_{2}$. The plates were then transferred to an atmosphere containing $3 \% \mathrm{CO}_{2}$ and incubated for a further $24 \mathrm{~h}$ at $37^{\circ} \mathrm{C}$. Of the $K$. ozaenae strains deprived of $\mathrm{CO}_{2}$ at $30^{\circ} \mathrm{C}, 15$ grew normally, the other five and the four $K$. pneumoniae strains failed to grow. After deprivation of $\mathrm{CO}_{2}$ at $41^{\circ} \mathrm{C}$ only one organism grew; this was a $K$. ozaenae.

\section{Prolonged incubation in $\mathrm{CO}_{2}$ and air}

Five strains of Klebsiella which grew well in air were subcultured daily in an atmosphere containing $3 \% \mathrm{CO}_{2}$ in an attempt to induce a cultural requirement for the gas. This attempt failed; there was no detectable change in the recovery rates after this treatment. However, two strains of $K$. pneumoniae which had shown a preference for $\mathrm{CO}_{2}$ became aerotolerant after daily subculture in air for one month.

\section{Effect of $\mathrm{pH}$ on growth}

Nutrient-agar plates buffered to $p \mathrm{H} 5 \cdot 7,7 \cdot 2,8 \cdot 5$ and 10.0 were inoculated with strains of $K$. ozaenae. Only a few colonies were observed after incubation 
in air at $37^{\circ} \mathrm{C}$ for $18 \mathrm{~h}$ on the plates at $p \mathrm{H} 5 \cdot 7,7 \cdot 2$ and $8 \cdot 5$. No growth was obtained at $p \mathrm{H} 10 \cdot 0$. Parallel cultures incubated in $3 \% \mathrm{CO}_{2}$ produced large mucoid colonies at all the $p \mathrm{H}$ values.

\section{Influence of antibiotics and other substances on growth}

Antimicrobial-sensitivity testing was done on $K$. ozaenae with Oxoid DST Agar incubated at $37^{\circ} \mathrm{C}$ in air for $18 \mathrm{~h}$. When a Mastring (Diamed Diagnostics Ltd) containing ampicillin, tetracycline, co-trimoxazole, cephalexin, colistin and gentamicin was used, a characteristic pattern of growth developed; the centre of the plate was free from organisms and what appeared to be a ring of stimulated growth was seen around the co-trimoxazole and tetracycline discs. The colonies were 1-2 mm in diameter and non-mucoid. Sensitivity-test plates incubated in $\mathrm{CO}_{2}$ produced mucoid growth with the following susceptibility pattern: moderately sensitive to ampicillin, tetracycline, co-trimoxazole; sensitive to cephalexin, colistin, gentamicin. Growth in air was stimulated by other unrelated substances including the antibacterial agents trimethoprim and clindamycin. The nature of the bacterial growth is shown in the figure. The growth appeared after $18 \mathrm{~h}$ as a ring of minute colonies which became larger and mucoid after $24 \mathrm{~h}$. Barium nitrate, $5 \%(\mathrm{w} / \mathrm{v})$, magnesium chloride, $5 \%$ $(\mathrm{w} / \mathrm{v})$ and dipotassium ethylene diamine tetra-acetate $0.1 \%(\mathrm{w} / \mathrm{v})$ produced a similar effect. The growth around a well of sodium barbitone $0.8 \%(\mathrm{w} / \mathrm{v})$, was almost the same as that obtained in $\mathrm{CO}_{2}$. None of the substances could replace $\mathrm{CO}_{2}$ because no growth was evident when the tests were made without $\mathrm{CO}_{2}$. A $3 \%(\mathrm{w} / \mathrm{v})$ solution of sodium bicarbonate enhanced the growth of most of the strains tested but did not replace atmospheric $\mathrm{CO}_{2}$.

\section{DisCUSSION}

We believe that $\mathrm{CO}_{2}$ dependence is a characteristic of $K$. ozaenae because all but one of the strains tested required a final concentration of $\mathrm{CO}_{2}$ of around $0.07 \%$ to produce typical mucoid "klebsiella colonies" after growth at $37^{\circ} \mathrm{C}$ for for $18 \mathrm{~h}$. The $\mathrm{CO}_{2}$ produced two observable changes: it increased the viable count compared with parallel aerobic cultures and stimulated the formation of mucoid colonies. K. ozaenae was not the only species with a preference for $\mathrm{CO}_{2}$; a few strains of $K$. pneumoniae had similar requirements and so did two strains of $K$. edwardsii var. atlantae. However, none of the $K$. aerogenes strains demonstrated a need for $\mathrm{CO}_{2}$.

The organisms requiring added $\mathrm{CO}_{2}$ for growth at $37^{\circ} \mathrm{C}$ grew in air at $30^{\circ} \mathrm{C}$ at the concentration of $\mathrm{CO}_{2}$ in the atmosphere and in this respect appeared similar to the staphylococci reported by Thomas (1977). As the temperature of incubation increased, the $\mathrm{K}$. ozaenae strains required more $\mathrm{CO}_{2}$; this was greatest at a temperature of $41^{\circ} \mathrm{C}$. Unlike $K$. aerogenes, the $K$. pneumoniae and most of the $K$. ozaenae strains did not survive after deprivation of $\mathrm{CO}_{2}$. The lowest survival rate was found at the higher temperatures of incubation.

Cultures of $K$. ozaenae grown at $37^{\circ} \mathrm{C}$ in air for $18 \mathrm{~h}$ often produced minute 


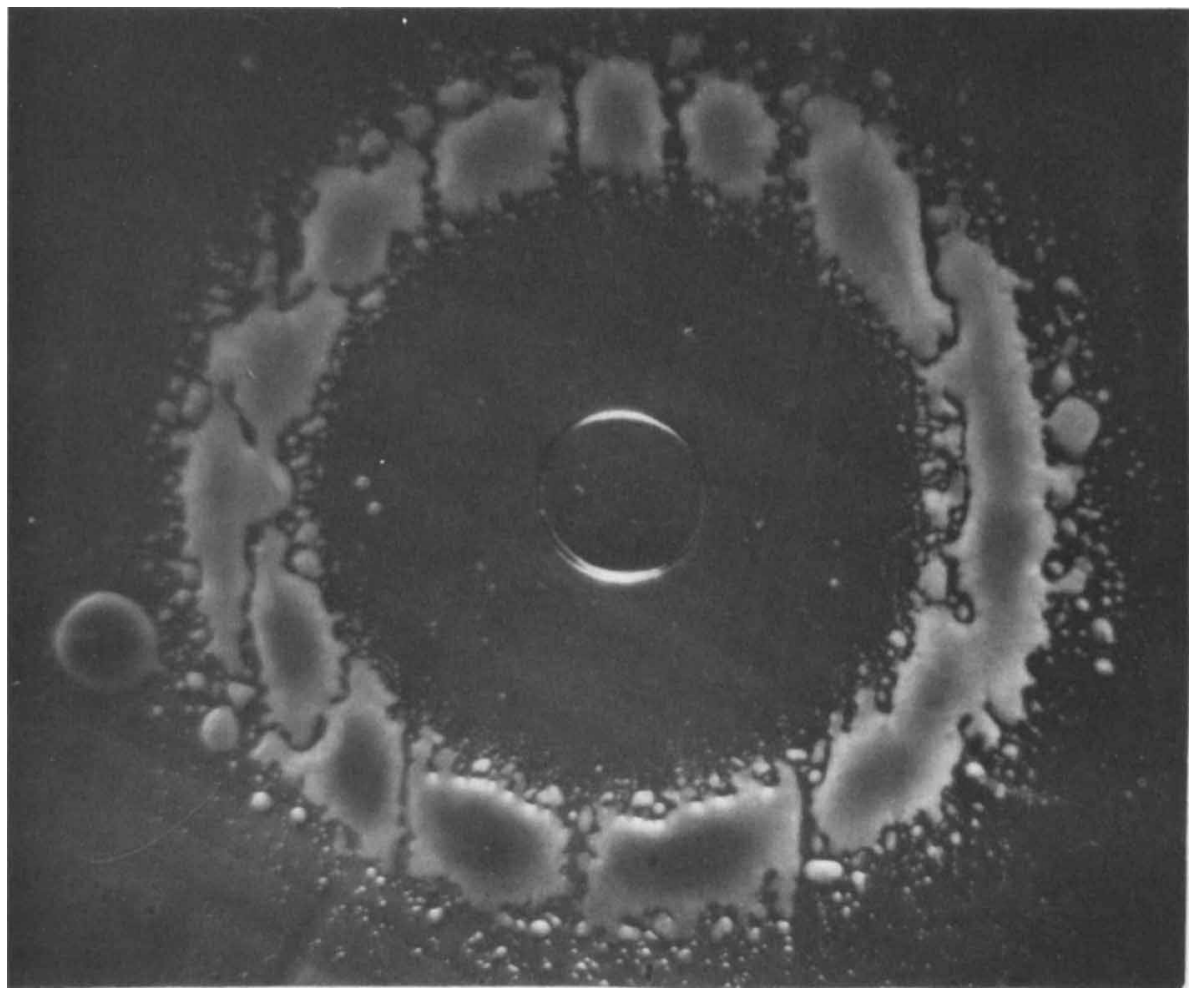

FigURE.- K. ozaenae on Oxoid DST Agar with added lysed horse-blood $5 \%(\mathrm{v} / \mathrm{v})$, growing around a well containing tetracycline $100 \mathrm{mg} /$ litre after incubation for $24 \mathrm{~h}$ at $37^{\circ} \mathrm{C}$ in air. The growth contains mucoid and non-mucoid colonies. 
colonies which could easily have been missed without close examination. After incubation for a further $18 \mathrm{~h}$ a mixture of small non-mucoid and large (3-4 mm diameter), mucoid convex colonies, typical of klebsiellae were produced. With the K. ozaenae strains subculture never yielded a pure growth containing only one type of colony.

Although we were unable to produce $\mathrm{CO}_{2}$ dependence in vitro, it seems significant that all our $\mathrm{CO}_{2}$-requiring organisms were isolated from the respiratory tract. Only a few were regarded as being clinically significant but many of the strains were found in bronchitic patients who are known to suffer from $\mathrm{CO}_{2}$ retention. This may account for the frequent isolation of these organisms from this site and their requirement for relatively small amounts of $\mathrm{CO}_{2}$. In substantiation of this hypothesis, we obtained typical mucoid growth by incubating plates at $37^{\circ} \mathrm{C}$ for $18 \mathrm{~h}$ in a plastic bag, filled by mouth with expired air and sealed.

An unusual characteristic of many of the $K$. ozaenae strains and of a recently isolated $S$. aureus requiring $\mathrm{CO}_{2}$ for growth at $37^{\circ} \mathrm{C}$, is the ability of the organism to grow in air at $37^{\circ} \mathrm{C}$ without added $\mathrm{CO}_{2}$ but in the presence of antibiotics and other unrelated substances. This phenomenon appeared similar to that described by McGhie, Hutchison and Finch (1972) in which the growth of a strain of $K$. aerogenes was stimulated by sulphonamides and other substances. Our organisms did not grow with the added substances except at the atmospheric concentration of $\mathrm{CO}_{2}$. The $S$. aureus demonstrated a similar growth enhancement with antibiotics, notably chloramphenicol and tetracycline and grew well at $30^{\circ} \mathrm{C}$ in air without added $\mathrm{CO}_{2}$. It may be that the gram-positive and gram-negative organisms exhibiting this type of dependence use similar metabolic pathways. It seems unlikely that the effect of $\mathrm{CO}_{2}$ is due simply to $p \mathrm{H}$ change because alteration in the $\mathrm{H}^{+}$ion concentration did not allow growth unless $\mathrm{CO}_{2}$ was present.

Dependence on $\mathrm{CO}_{2}$ for growth is a characteristic not usually associated with the Enterobacteriacae and may present the laboratory with difficulties in isolation, identification and antimicrobial sensitivity testing. We consider that any organism that grows poorly in air should always be tested for $\mathrm{CO}_{2}$ requirement because this may be more widespread than is generally recognised. Perhaps air containing extra $\mathrm{CO}_{2}$ should be regarded as "normal" for human pathogens and growth in ordinary air abnormal and fortuitous rather than the reverse (Stokes, 1975).

\section{Summary}

The growth of 95 strains of Klebsiella cultured in air with added $\mathrm{CO}_{2}$ is described. Twenty-two strains of $K$. ozaenae required $\mathrm{CO}_{2}$ for characteristic growth when cultured at $37^{\circ} \mathrm{C}$ and growth was promoted by co-trimoxazole, tetracycline and sodium barbitone. Four strains of $K$. pneumoniae, two of $K$. edwardsii var. atlantae and one of $K$. edwardsii var. edwardsii gave increased viable counts after incubation in $\mathrm{CO}_{2}$. None of the 40 strains of $K$. aerogenes tested required $\mathrm{CO}_{2}$ for growth. 
We are grateful to Dr J. G. P. Hutchison for his advice in preparing the manuscript and to Dr P. R. Mortimer of Coventry Public Health Laboratory for supplying strains of klebsiellae.

\section{REFERENCES}

Barker, J., Brookes, G. AND Johnson, T. 1978. Carbon dioxide dependent Klebsiellae. $B r$. med. J., $1,300$.

Cowan, S. T. 1974. Cowan and Steel's Manual for the identification of medical bacteria. Cambridge University Press: London, p. 110.

Eykyn, S. AND Phillips, I. 1978. Carbon dioxide-dependent Escherichia coli. Br. med. J., 1, 576.

HALE, J. H. 1951. Studies on staphylococcus mutation: a naturally occurring "G" gonidial variant and its carbon dioxide requirements. Br. J. exp. Path., 32, 307.

MCGhie, D., Hutchison, J. G. P. AND Finch, R. G. 1972. Stimulation of growth on a deficient medium of a Klebsiella aerogenes species by sulphonamide, para-amino benzoic acid, nitrofurantoin, and some other substance. J. clin. Path., 25, 976.

Stokes, E. J. 1975. Clinical bacteriology, 4th ed. Arnold: London, p. 13.

Thомas, M., 1977. Carbon dioxide dependent dwarf staphylococcus. Br. med.J., 2, 830. 